\title{
Sinclair Lewis and the Decline of ıLiberalismı
}

\author{
Reading It Can't Happen Here in the Age of Trump
}

Philipp Schweighauser

Fascism comes to the United States in the figure of Berzelius (»Buzz«) Windrip, a folksy western Senator who wins the 1936 presidential election. ${ }^{1}$ Once inaugurated, he moves quickly to disempower Congress, dismantle the separation of powers, disenfranchise African Americans, discriminate against Jews, and persecute communists. Dissent is quelled by the storm troopers of the "Minute Men« (or "M. M.»), a paramilitary force of thugs named after the revered militiamen of the American Revolution. Soon, political opponents are executed. Concentration camps are built. This is the bleak vision of Sinclair Lewis's dystopian novel It Can't Happen Here (1935). Lewis's character is based on the historical figure of Huey Long, a populist, authoritarian Democratic Governor and Senator who had presidential ambitions but was shot dead one month before the novel came out.

In US literary history, Lewis is better known for his skewering of middle-class mediocrity, materialism, and hypocrisy in novels such as Main Street (1920) and Babbit (1922), works that were singled out when he received the 1930 Nobel Prize in Literature. ${ }^{2}$ But once it became clear that Donald J. Trump was a serious contender for the US presidency, American journalists turned to Lewis's dystopia. Articles with titles such as »It Really Can Happen Here: The Novel that Foreshadowed Donald Trump's Authoritarian Appeal «, ${ }^{3}$ "How Does Donald Trump Stack Up Against American Literature's Fictional Dictators? Pretty Well, Actually ${ }^{4}$ and Creeping Fascism: Sinclair

\footnotetext{
I would like to thank Ridvan Askin for astute critical feedback, Rahel Ackermann Hui for her diligent proofreading and formatting, and Andrea Wüst for making helpful suggestions for cuts.

2 Erik Axel Karlfeldt, The Nobel Prize in Literature 1930: Award Ceremony Speech, in: Nobelprize.org December 10, 1930 https://www.nobelprize.org/nobel_prizes/ literature/laureates/1930/press.html (11.10.2017).

3 Malcolm Harris, It Really Can Happen Here: The Novel that Foreshadowed Donald Trump's Authoritarian Appeal, in: Salon, September 30, 2015 http://www.salon. com/2015/09/29/it_really_can_happen_here_the_novel_that_foreshadowed_donald_trumps_authoritarian_appeal/ (11.10.2017).

4 Carlos Lozada, How Does Donald Trump Stack Up Against American Literature's Fictional Dictators? Pretty Well, Actually, in: Washington Post, June 9, 2016 https://
} 
Lewis Warns Us It Can Happen Here- and Maybe It Is $\ll^{5}$ began to appear. Two days after the inauguration of the $45^{\text {th }}$ President, Beverly Gage published "Reading the Classic Novel that Predicted Trump" in The New York Times. ${ }^{6}$ These authors draw numerous parallels between Trump's rise and the ascendancy of Lewis's fascist dictator. Suffice it to mention but the most striking ones:Windrip is, like Trump, a nativist, a media-savvy entertainer, and a self-proclaimed champion of "forgotten men « ${ }^{7}$ He promises economic prosperity, ${ }^{8}$ vows to restore dignity to a white working class that feels left behind, ${ }^{9}$ and attacks the $" l i e s «^{10}$ of the mainstream media, professing to tell his audiences the truths that had been hidden from them. ${ }^{11}$ Both also fuel racist resentment and are dyed-in-the-wool populists. ${ }^{12}$ Moreover, Windrip's diabolical campaign strategist, intellectual guide, and future Secretary of State Lee Sarason is a newsman who resembles another, real-life newsman, Steve Bannon, who once said, surely in an offhandishly joking vein but also ominously, "Darkness is good [...] Dick Cheney. Darth Vader. Satan. That's power.$^{13}$ Writing for Salon, Malcolm Harris adds that Trump appears to take his nativism right out of Windrip's campaign book Zero Hour:

"My one ambition is to get all Americans to realize that they are, and must continue to be, the greatest Race on the face of this old Earth, and second, to realize that whatever apparent differences there may be among us, in wealth, knowledge, skill, ancestry or strength - though, of course, all this does not apply to people

www.washingtonpost.com/news/book-party/wp/2016/06/09/how-does-donaldtrump-stack-up-against-american-literatures-fictional-dictators-pretty-well-actually/ (11.10.2017).

5 Jim Swearingen, Creeping Fascism: Sinclair Lewis Warns Us It Can Happen Here - and Maybe It Is, in: The National Book Review, June 22, 2016 http://www. thenationalbookreview.com/features/2016/6/22/essay-creeping-fascism-sinclairlewis-warned-us-it-can-happen-here-and-maybe-it-is-starting (11.10.2017).

6 Beverly Gage, Reading the Classic Novel that Predicted Trump, in: New York Times, January 22, 2017 https://nyti.ms/2k1EBVz (11.10.2017).

7 Harris, It Really Can and Gage, Reading.

8 Gage, Reading.

9 Gage, Reading, and Harris, It Really Can.

${ }^{10}$ Sinclair Lewis, It Can't Happen Here [1935], London 2017, 34.

${ }^{11}$ Gage, Reading, and Lozada, Donald Trump.

${ }^{12}$ Gage, Reading, Lozada, Donald Trump, and Harris, It Really Can.

${ }^{13}$ Michael Wolff, Ringside With Steve Bannon at Trump Tower as the PresidentElect's Strategist Plots `An Entirely New Political Movement<, The Hollywood Reporter, November 18, 2016 http://www.hollywoodreporter.com/news/steve-bannontrump-tower-interview-trumps-strategist-plots-new-political-movement-948747 (11.10.2017). 
who are racially different from us-we are all brothers, bound together in the great and wonderful bond of National Unity, for which we should all be very glad. ${ }^{14}$

Ghostwritten by Sarason, Zero Hour is most visible in the novel as the source of epigraphs for chapters 5-20. As Carlos Lozada observes, even the novel's description of Zero Hour would fit Trump's The Art of the Deal: ${ }^{15}$ "part biography, part economic program, and part plain exhibitionistic boasting ${ }^{16}{ }^{16}$

Fueled to some extent by newspaper articles such as these and their dissemination via social media, It Can't Happen Here has returned to the bestseller lists. After the election on November 8, 2016, the novel sold out on Amazon.com. ${ }^{17}$ Shortly after Trump's inauguration on January 20, 2017, the novel saw another spike in sales, entering the top 10 of Amazon's bestseller list. ${ }^{18} \mathrm{~A}$ second indicator for its renewed popularity are Google searches for "It Can't Happen Here", which reached a five-year peak in the week of the 2016 election. ${ }^{19}$ Searches for "Sinclair Lewis" reached their five-year peak in the week following the inauguration. ${ }^{20}$

Interest over time $\pm \ll<$

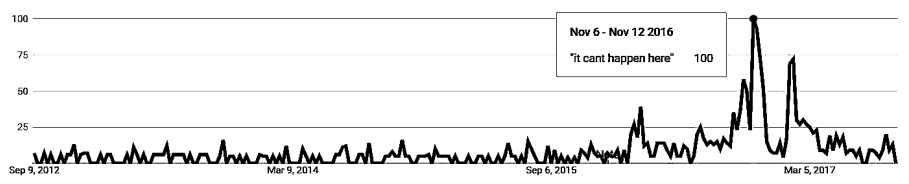

Data source: Google Trends (www.google.com/trends).

${ }^{14}$ Lewis, It Can't, 69, zit. in: Harris, It Really Can.

${ }^{15}$ Lozoda, Donald Trump.

${ }^{16}$ Lewis, It Can't, 29.

${ }^{17}$ Kerry Close, Sinclair Lewis Novel It Can't Happen Here Sells Out Online, in: TIME.com November 16, 2016 http://time.com/money/4573801/sinclair-lewis-itcant-happen-here-amazon/ (11.10.2017) and Gage, Reading.

${ }^{18}$ Brian Stelter, Amazon's Bestseller List Takes a Dystopian Turn in Trump Era, in: Money.cnn.com January 28, 2017 http://money.cnn.com/2017/01/28/media/ it-cant-happen-here-1984-best-sellers/index.html (11.10.2017) and Brian Wheeler, The Trump Era's Top-selling Dystopian Novels, in: BBC.co.uk January 29, 2017 http://www.bbc.co.uk/news/magazine-38764041 (11.10.2017).

19 "It Can't Happen Here«, Google Trends, September 9, 2012-September 9, 2017 https: //trends.google.com/trends/explore?date $=$ today $\% 205-\mathrm{y} \& \mathrm{q}=\% 22 \mathrm{it} \% 20$ cant $\% 20$ happen $\% 20$ here $\% 22$ (9.9.2017).

20 "Sinclair Lewis«, Google Trends, September 9, 2012-September 9, 2017 https:// trends.google.com/trends/explore?date $=$ today $\% 205-\mathrm{y} \& \mathrm{q}=\% 22$ sinclair $\% 20$ lewis $\% 22$ (9.9.2017). 


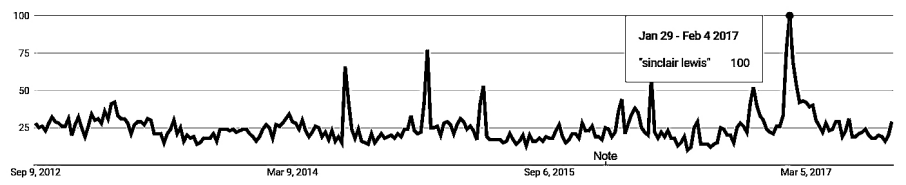

Data source: Google Trends (www.google.com/trends).

Lewis's novel shares its return to fame with other, more famous dystopian novels, including Nineteen Eighty-Four, Animal Farm, The Handmaid's Tale, and Fahrenheit 451. ${ }^{21}$ For American readers, though, it is It Can't Happen Here which hits closest to home as it imagines a country ruled by a plain-spoken fascist President.

The authors drawing comparisons between Windrip and Trump are well aware of their limitations. For one, Windrip is, like Huey Long, a Democrat, not a Republican. And while Trump's pronouncements do embolden fascists - one case in point is his claim that there were some "very fine people« among the August 2017 "Unite the Right" rally of white nationalists and neo-Nazis in Charlottesville, Virginia ${ }^{22}$ - it is unclear whether Trump himself holds fascist or antisemitic views (the racism question seems settled, though). Finally, while his moves to deport »illegal immigrants « and his verbal aggressions against Mexico and North Korea are causes for great outrage, he is unlikely to build concentration camps. In historian Gage's words, "the graphic horrors of Lewis's vision also limit the book's usefulness as a guide to our own political moment ${ }^{23}{ }^{23}$

Still, Harris, Lozada, Swearingen, and Gage are united in their belief that the parallels are close enough to warrant serious concern. I share this concern, but I am most intrigued by another conviction that these commentators - and other journalists such as Carla Seaquist and Alexander Nazaryan ${ }^{24}$ - give expression to. It con-

\footnotetext{
${ }^{21}$ Sophie Gilbert, 1984 Isn't the Only Book Enjoying a Revival, in: The Atlantic, January 25, 2017 https://www.theatlantic.com/entertainment/archive/2017/01/1984george-orwell-alternative-facts-trump-kellyanne-conway/514259/ (11.10.2017).

${ }^{22}$ Donald J. Trump, Remarks by President Trump on Infrastructure, in: Whitehouse. gov August 15, 2017 https://www.whitehouse.gov/the-press-office/2017/08/15/ remarks-president-trump-infrastructure (11.10.2017).

${ }^{23}$ Gage, Reading.

${ }^{24}$ Carla Seaquist, Books for Our Times: >It Can't Happen Here , by Sinclair Lewis (a Novel), in: Huffington Post, October 1, 2016 http://www.huffingtonpost.com/carlaseaquist/books-for-our-times-it-ca_b_12261058.html (11.10.2017) and Alexander
} 
cerns the novel's protagonist, who is neither Windrip nor Sarason but Doremus Jessup, the publisher and editor of The Daily Informer, the local newspaper of fictitious Fort Beulah, Vermont. About him, Harris writes, "Jessup's liberalism looks more like a combination of laziness and cowardice than conviction. He doesn't know where the line is between what he can accept and what he can't, nor what he's prepared to do once the line is crossed «. ${ }^{25}$ Gage agrees, arguing that "the book skewers Jessup's passivity" as part of Lewis's determination "not only to satirize American liberals, but to induce them to pay attention before it's too late «. ${ }^{26}$ Drawing more explicit parallels between the fascist threat of the 1930s and the Trump presidency, Nazaryan strikes a similar note: "In some ways, Jessup is the predecessor of today's coastal liberal who did fine during the Great Recession of 2008 and doesn't entirely understand the rage of those who fervently believe in America's decline «. ${ }^{27}$ Seaquist seconds this assessment: "as is often true of liberals and intellectuals, [Jessup] feels helpless in the face of force and violence-much like liberals feel vis-à-vis Trump « ${ }^{28}$ Writing for media outlets that Trump and his supporters revile as "mainstream media" and "fake news", these commentators are united in their sense of urgency as they read the novel as a premonitory narrative about the dangers of liberal acquiescence in the age of Trump. And they are not alone: the blurb on the backcover of the 2017 Penguin edition describes the novel as a "cautionary tale of liberal complacency in the face of populist tyranny".

The problem with such readings of the novel is that they are not borne out by the story that it tells.

Before we consider the novel's stance on liberalism, a clarification concerning the meaning of the term is in order. In Europe, »liberalism" refers to a political idea that champions limited government, laissez-faire economic policies, and private property as core foundations of individual liberty - central tenets of both "classic liberalism" and "neoliberalism». In the US, "liberalism" means something different: there, it refers almost exclusively to what has variously been labelled "new liberalism«, "social liberalism", or "welfare state liberalism«. US liberals position themselves on the moderate political left, arguing for the abolishment of neither private property,

Nazaryan, Getting Close to Fascism with Sinclair Lewis's It Can't Happen Here, The New Yorker, October 19, 2016 https://www.newyorker.com/culture/culture-desk/ getting-close-to-fascism-with-sinclair-lewiss-it-cant-happen-here (11.10.2017).

${ }^{25}$ Harris, It Really Can.

${ }^{26}$ Gage, Reading.

${ }^{27}$ Nazaryan, Getting Close.

${ }^{28}$ Seaquist, Books. 
nor capitalism, nor the state while maintaining - and this is what sets American liberalism apart from its European namesake - that a free market based on private property is likely to generate unjust equalities of power that the government has a duty to redress. For them, the government ought to play a significant role, not only in regulating the economy but also in remedying social ills such as poverty, racial discrimination, and sexism that curb people's capacity for self-realization. Franklin D. Roosevelt's New Deal economics in response to the Great Depression and Lyndon B. Johnson's Great Society, which sought to eliminate poverty and racism, are key reference points that exemplify US liberalism's commitment to social justice, welfare-state policies, redistribution, and civil rights. US liberalism, then, has a strongly egalitarian outlook and shares core ideological convictions with European social democracy. Its latest major legislative accomplishment is the Affordable Care Act.

On the opening pages of It Can't Happen Here, Lewis quickly establishes his 60-year-old protagonist as a liberal in this sense. Attending a dinner organized by the local Rotary Club, Jessup sarcastically comments on the various speeches given there without openly challenging the speakers' sexism, anti-communism, and militarism the way his more ardent friend Lorinda Pike does. Unlike her, he is a liberal with no radical inclinations. Jessup, who voted for Roosevelt in the 1932 election, ${ }^{29}$ repeatedly self-identifies as a liberal:»He, who understood himself abnormally well, knew that far from being a leftwing radical, he was at most a mild, rather indolent and somewhat sentimental Liberal [...]. But for all cruelty and intolerance, and for the contempt of the fortunate for the unfortunate, he had not mere dislike but testy hatred. ${ }^{30}$ Jessup's self-assessment is tinged with a dose of self-deprecating irony, but his opposition to cruelty - the defining liberal stance according to Judith Shklar and Richard Rorty stands firm. ${ }^{31}$ Unlike many of his acquaintances, Jessup perceives the fascist threat posed by a Windrip presidency clearly, telling them that the country's history of racist, anti-communist, and anti-Catholic violence ensures that it can happen here: "Why, where in all history has there ever been a people so ripe for a dictatorship as ours! «. ${ }^{32}$ But Jessup's liberal convictions are soon put to the test. Once Windrip

${ }^{29}$ Lewis, It Can't, 46.

${ }^{30}$ Ibid.

${ }^{31}$ In Shklar's words, »liberal and humane people, of whom there are many among us, would, if they were asked to rank the vices, put cruelty first. Intuitively they would choose cruelty as the worst thing we do" (Ordinary Vices, Cambridge, 1984, 44). See also Rorty, Contingency, Irony, and Solidarity, Cambridge, 1989, 173).

${ }^{32}$ Lewis, It Can't, 17. 
is in office, he acts quickly to build a fascist "Corporate State«, and Jessup does nothing but talk while Congress is stripped of power, Minute Men kill demonstrators, a state of emergency is declared, and concentration camps are built. ${ }^{33}$ It takes the casual murder of two old men by the drunk Secretary of Education to jolt Jessup into action. Against the opposition of his head compositor and his wife, he publishes a forceful editorial: "It is easy to see now, in the revolting crime of a drunken cabinet member against two innocent and valuable old men $[. .$.$] that we may expect nothing but murderous$ extirpation of all honest opponents of the tyranny of Windrip and his Corpo gang ${ }^{34}{ }^{34}$

The Corporate State's response is swift: Jessup is removed as editor but told to write editorials friendly to the fascist regime while his more ardent son-in-law is executed on the spot for intervening on his behalf. ${ }^{35}$ Back at the Informer, Jessup goes into internal exile, writing lukewarm editorials which the new editor rewrites as paeans to the fascist state. After the town's hardware dealer and a Jewish friend of his are sent to concentration camp, Jessup decides to "make amends to his conscience«, leave the newspaper, and "[d]o a little high treason «. ${ }^{36}$ Though by no means sympathetic to communism, he offers his services to the communist resistance but is disgusted by its leadership's self-righteousness and doctrinairism. He leaves them with these words: "But I just wonder if Walt Trowbridge won't be chasing out Buzz Windrip while you boys are still arguing about whether Comrade Trotzky was once guilty of saying mass facing the north? Good-day! ${ }^{37}$ Trowbridge, Windrip's Republican opponent in the presidential election, now leads a resistance movement uniting democrats and socialists from his Canadian exile. Jessup founds the "Fort Beulah cell of the N.U." ${ }^{38}$ Trowbridge's »New Underground". $\mathrm{He}$ is joined by about two dozen co-conspirators and sets up a clandestine print shop to disseminate anti-fascist newspapers and pamphlets that expose the crimes of the regime. When he is found out, he is tortured, convicted of "seditious activities $«,{ }^{39}$ and sent to concentration camp. There, he is beaten, flogged, and witnesses the killings of several friends. With the help of a bribe, Jessup manages to escape after six months. He is nursed back to strength and flees to

\footnotetext{
${ }_{33}$ Lewis, It Can't, 35-36, 138-139, 140-141, 159.

34 Ibid., 172-173.

35 Ibid., 194-196.

36 Ibid., 243, 248.

37 Ibid., 252.

38 Ibid., 259.

39 Ibid., 306.
} 
democratic Canada. But Jessup decides to return to the US for the "highest honor a man could earn" in the eyes of the N.U. leaders: »to be permitted to risk his life for truth, without pay or praise $\|^{40}$ When an armed "popular rebellion against the whole Corpo régime «1 breaks out, Jessup eagerly returns to Minnesota to support it as a political agitator. ${ }^{42}$ The novel ends with a mildly ironic yet sympathetic look at Jessup; he rides, not quite into the sunset, but into the sunrise: "And still Doremus goes on in the red sunrise, for a Doremus Jessup can never die . $^{43}$

Is this the story of a complacent liberal? Up to a point, the novel invites such a reading since Jessup himself, who consistently selfidentifies as a liberal, repeatedly questions his own resolve in the face of fascism. In oft-quoted words, he berates himself for not responding earlier and more forcefully: "The tyranny of this dictatorship isn't primarily the fault of Big Business, nor of the demagogues who do their dirty work. It's the fault of Doremus Jessup! Of all the conscientious, respectable, lazy-minded Doremus Jessups, who have let the demagogues wriggle in, without fierce enough protest $« .{ }^{44}$ Jessup knows full well that he is but a "small-town bourgeois Intellectual «. ${ }^{45}$ It is true, then, that Lewis's protagonist at first fails to fully realize the seriousness of the fascist threat and then hesitates to act, both because he fears persecution and because his politics are liberal, not radical. It is only in chapter 25 of this 38-chapter novel that he joins the resistance.

But is Jessup's liberalism »skewer[ed] $^{46}$ by Lewis to expose its "laziness and cowardice ${ }^{47}$ its "helpless[ness] in the face of terror and violence ${ }^{48}{ }^{8}$ ? Note that this question is different from my earlier question about Jessup's politics and its adequacy in the face of a fascist regime. This question zooms in on the novel's attitude toward its protagonist. If we ask it, we find that It Can't Happen Here consistently affirms Jessup and the liberal values he represents. This becomes clearest when his actions are contrasted with those of politically more radical characters. We have already encountered his angry farewell

\footnotetext{
${ }^{40}$ Lewis, It Can't, 369.

${ }^{41}$ Ibid., 371.

${ }^{42}$ Ibid., 373-374. At this point in the narrative, the President is Dewey Haik, who has dispatched Sarason, who has himself deposed Windrip a short while ago.

${ }^{43}$ Ibid., 381.

${ }^{44}$ Ibid., 186.

${ }^{45}$ Ibid., 47.

${ }^{46}$ Gage, Reading.

${ }^{47}$ Harris, It Really Can.

${ }^{48}$ Seaquist, Books.
} 
to the communist leadership. Significantly, there is no voice that qualifies Jessup's sarcasm in that scene: neither Jessup's own, nor another characters', nor the narrators'. The communist characters in particular are drawn as ideologues who are as doctrinaire and as dangerous as the fascists they fight. At one point, Jessup rails against »the propaganda-aëroplane damn nonsense of Marx and Moscow" as he brushes off his communist acquaintance Karl Pascal: "Listen, Comrade Karl, Windrip and Hitler will join Stalin long before the descendants of Dan'l Webster. You see, we don't like murder as a way of argument - that's what really marks the Liberal! «. ${ }^{49}$ Four years after Lewis wrote this, the Molotov-Ribbentrop Pact confirmed his protagonist's suspicions.

The narrator's voice is an especially good indicator of the novel's stance on a variety of political ideas. Frequently sarcastic, he reserves his harshest judgments for the fascists; but the communists get their fair share too: their major magazine, The New Masses, is savaged for its "pious smugness unshaken by anything that had happened since 1935 " and its vilification of "all agents of the New Underground, including those who had been jailed and killed, as reactionary stool pigeons for Fascism « ${ }^{50}$ Communist diatribes like these, the narrator adds sarcastically, are "all nicely decorated with a Grooper cartoon showing Walt Trowbridge in M. M. uniform, kissing the foot of Windrip " ${ }^{51}$ None of the liberal characters receive such harsh treatment. At most, we get the kind of mild irony that we encounter when we read about Jessup believing that the historians who will write about the 1930s will be "neither Communists nor Fascists nor bellicose Americans or English Nationalists but just the sort of smiling Liberals that the warring fanatics of today most cursed as weak waverers . $^{52}$ In sum, It Can't Happen Here does not deliver the "cautionary tale of liberal complacency" promised by both the backcover of the 2017 Penguin edition and by journalists rediscovering the novel in the age of Trump. Perhaps, Jessup's first name, Doremus, connotes less sleepiness (Latin »dormio«; French »dormir"), as Swearingen suggests, than adoration (the "adoremus" - "we adore« - of Latin liturgy). ${ }^{53}$

Note that this does not amount to saying that Lewis proposes liberalism as an adequate response to fascism; he proposes no ready

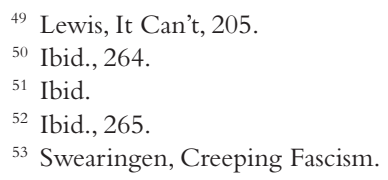


solution. Among the ideological options available though, Jessup's liberalism is consistently privileged vis-à-vis other choices. Crucially, Lewis emphasizes that his protagonist sticks to his liberal convictions at great personal risk. After all, Jessup joins the resistance and rejoins it as a liberal after surviving internment in a concentration camp, running "a very fair risk of being flogged to death ${ }^{54}$ when he returns to the fascist US after his brief Canadian exile. It Can't Happen Here, then, does not propose liberalism as the solution but it does affirm it as the most viable ethical and political stance.

Given this, how can we explain various twenty-first-century commentators' readings of the novel as a critique of liberal selfsatisfaction? To many left-leaning (liberal, radical, progressive) Americans, Trump's ascendancy and election came as a shocking surprise. In seeking answers to how this could happen in dystopian fictions, journalists readily found the closest analogy in It Can't Happen Here. But for many observers on the left, explanation is not enough; journalists writing for left-leaning media outlets felt that this election required a more activist response. To readers of the Hermeneutische Blätter, it will come as no surprise that Lewis's novel does not provide a blueprint for such action; with the possible exception of overtly committed writings such as Lydia Huntley Sigourney's protest poems against Indian removal and Upton Sinclair's The Jungle, literary texts hardly ever do that, and the vast majority of writers does not consider this the business of literature. Thus, if journalists were looking for viable models for resistance in Lewis's novel, they were thwarted. That they may indeed have been looking for such models can be glimpsed in their attempts to interpret the novel's ending as a call to trade liberalism in for radical, violent acts of resistance. Gage writes that "[b]y the book's closing pages, Jessup has returned to the United States as a disciplined resistance fighter, organizing armed rebellions throughout the Midwest $" .{ }^{55}$ Harris argues in a similar vein, "[o]nce Jessup has lost the privileges that kept him complacent, his deeply held commitment to nonviolent reform fades quickly «, ${ }^{56}$ and so does Seaquist: "Doremus' evolution to heroic action gives the novel its human thrill«. ${ }^{77}$

True, there is one sentence, on the novel's penultimate page, that does show Jessup ordering a military operation: "Oh, Lord, I don't want to, but I suppose I'll have to order the attack on the M.M. post

${ }^{54}$ Lewis, It Can't, 375.

55 Gage, Reading.

${ }^{56}$ Harris, It Really Can.

${ }^{57}$ Seaquist, Books. 
at Osakis now; they're ready for it ${ }^{58}{ }^{58}$ But to interpret this sentence as proof of Jessup's desertion of liberalism is not convincing, for three reasons. First, Lewis confines this hint at Jessup's newfound militancy to this single sentence. Second, even here, Jessup is still given to the wavering both he and present-day interpreters consider characteristic of liberals. Finally, it is unclear whether his newfound role within the resistance centers around militant action or around what Trowbridge actually orders him to do: "proselytizing in Minnesota «. ${ }^{59}$ Consider also that, in the final scene that shows Jessup talking to a politically more radical figure, the communist Karl Pascal, we find him reaffirming his liberal aversion to political radicalism even as they are interned in Trianon Concentration Camp: "the growing bitterness and orthodox piety of Karl became one of Doremus's most hateful woes ${ }^{60}{ }^{60}$ There is simply no indication that Jessup switches his ideological allegiances before his turn to militant action. In short, if the ending of the novel signals its protagonists' turn to militancy, it either comes out of nowhere or is a turn to militancy out of the spirit of liberalism. This may sound contradictory to twenty-firstcentury readers, who may equate liberalism with complacency. But we should not forget that two of the major American struggles for liberty born out of liberal natural rights philosophy - the colonies' fight for independence and abolitionism - were resolved in wars.

Admittedly, such historical arguments are of limited value because the Lockean liberalism that inspired the American Revolution and opposition to slavery provides a foundation for much more than social justice liberalism, most prominently capitalism, classic liberalism, and neoliberalism. We should also be wary about lumping together several historically distinct senses of »liberalism" because Jessup's brand of liberalism not only entails "admiration « ${ }^{61}$ for the towering liberal figure of Roosevelt but also comes with veneration for nineteenth-century figures that do not easily fit into the liberal pantheon: the abolitionist Republican congressman Thaddeus Stevens, the Democratic advocate of popular sovereignty Stephen A. Douglas, and legendary frontiersman Kit Carson. Jessup's liberalism is strongly aligned with an "essentially nineteenth-century evocation of self-reliant virtues ${ }^{62}$ that he most forcefully expresses after ano-

\footnotetext{
${ }^{58}$ Lewis, It Can't, 380 .

59 Ibid., 373.

${ }^{60}$ Lewis, It Can't, 356.

${ }^{61}$ Ibid., 356.

${ }^{62}$ Michael Meyer, Introd., in: It Can't Happen Here, by Sinclair Lewis. New York, 2014, v-xv, here xiv.
} 
ther dispute with comrade Pascal: »More and more, as I think about history $[\ldots]$ I am convinced that everything that is worth while in the world has been accomplished by the free, inquiring, critical spirit, and that the preservation of this spirit is more important than any social system whatsoever.$^{63}$

In the end, recent commentators' readings of It Can't Happen Here as a reckoning with "liberal complacency" are based less on an assessment of the novel's politics of representation than on an aversion to "liberalism« at a time in history when the label has lost much of its appeal. Once a term under which a majority of moderates and leftists could unite, a term that resonated powerfully with the legacies of the New Deal and the Great Society, a political idea that Lionel Trilling in 1950 pronounced the country's »sole intellectual tradition « ${ }^{64}$ "liberalism « has lost its unifying force. In the early twenty-first century, few US politicians self-identify as »liberals". More often than not, the label is used as a smear against ideological opponents. This is as true for right-wing denigrations of »libtards" as it is for leftist mockeries of »bleeding-heart liberals". During the 2016 presidential race, many supporters of Bernie Sanders were adamant about their opposition to Hillary Clinton, whose "liberalism « they equated with elitism, spinelessness, politics-as-usual, and submissiveness to corporate power. Among a sizeable minority of Sanders supporters (the "Bernie or bust" faction), opposition to Clinton's "liberalism" was strong enough to consider her unelectable even when the choice was narrowed down to her or Trump. Of course, Bernie supporters' aversion to Clinton owed much to positions of hers that many a right-thinking leftist would readily interrogate (e.g. her close ties to Wall Street, her hawkish foreign policy, and her support of Israel). Moreover, opposition to Clinton reached new heights when emails testifying to the Democratic National Committee's determination to undermine Sanders's campaign were leaked. But quite independent of these policy differences and revelations, the election showed the deep rift between leftists who self-identify as "democratic socialists" (Sanders's own label), progressives (a label that has a complex, contradictory history of its own), or radicals - and liberals. "For the committed leftist " of the early twenty-first century, Nikil Saval notes, sthe lliberak is a weak-minded, market-friendly centrist, wonky and technocratic and condescending to the working

\footnotetext{
${ }^{63}$ Lewis, It Can't, 359.

${ }^{64}$ Lionel Trilling, The Liberal Imagination: Essays on Literature and Society, New York, 1976, 15.
} 
class ${ }^{65}{ }^{65}$ From this perspective, liberalism is an ideology that champions diversity but is out of touch with the needs of average Americans, who are further alienated by what Emmett Rensin has diagnosed as liberalism's "smug style ${ }^{66}{ }^{6}$ "Liberalism $«$ in this sense denotes an elite "abandonment of class politics and radical thinking ${ }^{67}{ }^{67}$

As Henry Wismayer argues persuasively, this fall from grace of "liberalism" has its origins in the 1990s, when Tony Blair and Bill Clinton began to embrace a "third way" politics that aligned social liberalism with economic liberalism. This gave both right-wing critics of globalism and left-wing detractors of neoliberalism the opportunity to conflate the two and reject the whole package:

"[I]n the wake of the 2008 crash, [...], the sick underbelly of neoliberalism was exposed. For right-wing populists [...], this presented an opportunity to blur the lines between the two types of liberalism as part of a concerted project to demonize the status quo. Social and economic liberalism became a single entity, and suddenly, the left could be blamed for the damage wrought by a right-wing agenda, with establishment figures like Hillary Clinton portrayed as architects (rather than the inheritors) of an unforgivable betrayal. ${ }^{68}$

Recent readings of It Can't Happen Here that identify its protagonist as one of the novel's main ideological targets must be understood against the background of this decline of "liberalism" as a political label. What reviews of the novel in the age of Trump do is impose a deprecative twenty-first-century understanding of "liberalism " on a book whose liberal protagonist is anything but its whipping boy and whose brand of liberalism is patently different from what many on the left associate with the label today. Clearly, then, the novel stages no reckoning with "liberal complacency«. Michael Meyer's account of the author's admiration for his protagonist further corroborates this: "Lewis clearly admired and identified with Jessup—so much

\footnotetext{
${ }^{65}$ Nikil Saval, Hated by the Right, Mocked by the Left: Who Wants to Be `Liberak Anymore? In: New York Times, July 5, 2017 https://nyti.ms/2tL6wRI (11.10.2017).

${ }^{66}$ Emmett Rensin, The Smug Style in American Liberalism, in: Vox, April 21, 2016 https://www.vox.com/2016/4/21/11451378/smug-american-liberalism (11.10.2017). ${ }^{67}$ Conor Lynch, Why We Need the Left-wing Critique of Liberalism: Because Liberals Got Us Where We Are Today Salon, July 8, 2017 http://www.salon. com/2017/07/08/why-we-need-the-left-wing-critique-of-liberalism-because-liberals-got-us-where-we-are-today/ (11.10.2017).

${ }^{68}$ Henry Wismayer, The Crisis of Liberalism, Part I, in: Los Angeles Review of Books January 9, 2017 https://lareviewofbooks.org/article/crisis-liberalism-part/ (11.10.2017).
} 
so that he played the role of Jessup in a dramatic adaptation by the South Shore Players in Cohasset, Massachusetts «. ${ }^{69}$

We have become wary of the kinds of truth claims that Theodor W. Adorno still confidently made about works of art. Moreover, Adorno would certainly have censured Lewis's forage into littérature engagé as a "culinary work of art ${ }^{70}$ that fails to be truthful, consisting, as it does, of a "conjunction of readily graspable plots and equally graspable and distillable ideas $"{ }^{71}$ But if we retain a more modest sense of "truth " and apply it to the activity of literary interpretation, we can say with conviction that recent reviews of Lewis's novel fail to be truthful in that they impose present-day values and convictions on a text that was published over 80 years ago. In these presentist readings, the novel's ideological alliances are misunderstood as a fictional figure is taken to task for the US left's failure to prevent the election of a president whom The Huffington Post characterized thus in an editorial note added to the end of all reports about him during election season: »Editor's note: Donald Trump regularly incites political violence and is a serial liar, rampant xenophobe, racist, misogynist and birther who has repeatedly pledged to ban all Muslims-1.6 billion members of an entire religion - from entering the US«. This note gives expression to a core of truth that also energizes present-day misreadings of Lewis's novel. Yet unlike these interpretations, the note itself retains its truth value - even after The Huffington Post pulled it once Trump was elected so as to start with a "clean slate«. ${ }^{72}$

- Philipp Schweighauser is Associate Professor and Head of American and General Literatures at the University of Basel. His research focuses on 18th to 20th American literature and culture; literary, cultural, and media theory; literature and science; sound studies; and aesthetics.

\footnotetext{
${ }^{69}$ Meyer, Introduction, $\mathrm{x}$.

${ }^{70}$ Theodor W. Adorno, Commitment, in: Notes to Literature, ed. Rolf Tiedemann, transl. Shierry Weber Nicholsen, New York 1992, 76-94, here 92. Adorno's target here is Sartre's plays.

${ }^{71}$ Ibid., 81.

${ }^{72}$ Hadas Gold, The Huffington Post Ending Editor's Note that Called Donald Trump ‘Racistı, in: Politico, November 11, 2016 http://www.politico.com/blogs/ on-media/2016/11/the-huffington-post-ending-its-editors-note-about-donaldtrump-231044 (11.10.2017).
} 